Online Journal of Biological Sciences 6 (2): 71-73, 2006

ISSN 1608-4217

(C) 2006 Science Publications

\title{
Changes in Erucic Acid Concentration of Rape Seeds in Advanced Generations
}

\author{
${ }^{1}$ Selim Aytaç ${ }^{2}$ Şahin Gizlenci ${ }^{2}$ Mustafa Acar and ${ }^{3}$ Ali Üstün \\ ${ }^{1}$ Faculty of Agriculture, Department of Agronomy University of Ondokuz Mayıs \\ Kurupelit, Samsun, Turkey \\ ${ }^{2}$ Black Sea Agricultural Research Institude, Samsun, Turkey \\ ${ }^{3}$ Bahri Dağdaş International Agricultural Research Institude, Konya, Turkey
}

\begin{abstract}
This study was carried out to determine the extend of changes in erucic acid concentration of rapeseeds which were grown in Carsamba and Bafra Plains of Central Blacksea Region. In addition to field experiments, the same experiment was conducted in the greenhouse to avoid polen transfer from other sources. The first material used was 00 type rapeseed cultivars. In order to ensure a good result, the experiment sites were selected based on the intensity of other Brassica species (B. oleracea, B. rapa, B. nigra). The harvested rape seeds was the seed material of following year. Erucic acid content was measured for seeds obtained each year. The erucic acid content for three genarations showed that it was much lower than the limits for health $(0.04 \%)$
\end{abstract}

Key words: Brassica napus, fatty acid, cross, pollination

\section{INTRODUCTION}

Rape seed and oil turnip seeds before 1980s had more erucic acid content compared to the seeds of recent varieties. Therefore, rape seeds with high erucic acid content have been defined as old type. Rapeseed should have erucic content lower than $2 \%$ for human consumption $^{[1]}$. Breeding of low erucic acid resulted in types which have practically $0 \%$ erucic acid ${ }^{[2]}$.

Seed shattering before the harvest is often a problem. This problem comes out with the old types more frequently and as a result, some old type rape seed can be seen in fields. Although, there are no cultivation of old types, there might be some plants of these rape seeds with high erucic acid content have survived in field border and in the bank of field roads.

The studies on the inheritance of erucic acid content in oil turnip showed that there are two gene pairs controlling erucic acid, and this trait changed from year to year ${ }^{[3]}$. Fernandez-Escobar et al. ${ }^{[4]}$ found that two genes, one from genome $\mathrm{B}$ (EC) and the other from genome $\mathrm{C}$ (EC), in a additive gene action. Auld,-DL. et $a l^{[5]}$, conducted a study on B. campestris, B. napus, B. oleracea ve $B$. Carinata, and found that other fatty acids were more stable than erucic acid. Instability of erucic acid may suggest that percentage of this acid miaght be increased after a few generations if the seeds are not renewed.

Rape seed is a self pollinated crop with a $12-47 \%$ cross pollination rate ${ }^{[6,7]}$. If there was a growing " 00 " type cultivar in a region, there could be some changes in erucic acid content due to some cross pollination in case seeds were not renewed and old types were grown.
Khan ve ark. ${ }^{[8]}$ reported that erucic acid content was $0.8 \%$ in the first year in oil turnip. However, this rate was increased to $25.5,26.6$ and $22.7 \%$ in following years when seeds were not renewed. They suggested that this result came out because of crosspollination with local lines.

Bilsbarrow et al. ${ }^{[9]}$ studied the changes of erucic acid in "00" types in two locations in England. They found that erucic acid content was increased $20 \%$ because of cross pollination with high erucic acid types around, and these "00" types lost their " 00 " characteristics. They also point out that cross pollination was the result of insect population but not that of wind. When the distance between varieties was increased, cross pollination rate was decreased. They concluded that if rape seed field was large enough, there could not be a serious erucic acid problem in case old and new types were grown adjacent fields.

Öktem $^{[10]}$, studied the effects of seeds renewal on erucic acid content between 1982-1986 in Tarsus with winter varieties Quinta, Stasus, Primor ve St. 1348. He did not renew seeds and found out that erucic acid ratio was changed between 7.51 and $20.82 \%$. He concluded that seeds should be renewed because erucic acid content was higher than $5 \%$ and cross pollination rate was $35 \%$ in rape seeds.

Yield decrease in synthetic varieties was lower than hybrid varieties in successive years ${ }^{[7]}$. Therefore, synthetic varieties can be grown for several years without renewing seeds. However, if this lead increase in erucic acid content, oil obtained from these seeds were not suitable for human health. Results of studies above show the probability of cross pollination in presence of old types in the flora.

Corresponding Author: $\quad$ Dr. Selim Aytac, Faculty of Agriculture, Department of Agronomy, University of Ondokuz Mayis, 55139 Kurupelit/Samsun, Turkey, Tel: +90-362-312 1919 x 1176, Fax: +90-362-4576034 
However, in presence of cabbage (B. oleraceae) and turnip (B. rapa), there is not any result, which shows the change in erucic acid content.

Cabbage and turnip which are wild relatives of rape seed are produced commonly in Çarşamba and Bafra Plains, where there is enormous rape seed production potential, There was not any rape seed production in these plains in the past. There is a need to study the potential of cross pollination of rape seed with its relatives and changes in erucic acid content.

\section{MATERIALS AND METHODS}

The plant material was French Bristol and German Licrown synthetic varieties. Both varieties were "00" type. The study was conducted in 3 years. Three years field work was the material preparation stage and carried out in 2 locations, Çarşamba and Bafra Plains. Also, there was the same set of material in the greenhouse to prevent cross pollination with relative species. It was given a special attention to choose fields for experimantation with a common Brassica species (B. oleraceae and B. rapa) in order to get a clear picture of cross pollination between rape seed and other Brassica species and its effect on erucic acid content. Greenhouse material would show the effect of cross pollination among rape seed varieties aand its effect on erucic acid content. The material preparation scheme was as follows:

Year 1: Varieties Bristol and Licrown was grown in two location in a completely randomized block design with 4 replicates. The plots were $10 \mathrm{~m}^{2}$ with 10 rows and $20 \mathrm{~cm}$ row spacing. Experiments were planted in the second half of september, and seed rate was $10 \mathrm{~kg}$ $\mathrm{ha}^{-1}$. Nitrogen and phosphorus fertilizers were $120 \mathrm{~kg}$ $\mathrm{ha}^{-1}$ and $80 \mathrm{~kg} \mathrm{ha}^{-1}$. Yield and its components were recorded and seed for the year 2 was saved from the first year grown plants (G1 - First year generation). 100 $\mathrm{g}$ seeds from each plot were saved for erucic acid and glicosinlat analysis.
Year 2: As in the first year, both varieties were tested in both locations in a completely randomized block design with 4 replicates, and seed of G1 genaration were grown in a completely randomized block design with 3 replicates in field and greenhouse experiments. The plot size was $5 \mathrm{~m}^{2}$ in the green house experiment. Seeds from G1 and G2 genarations were saved for following year. Yield and its components were recorded in all experiments, and seed samples from each plot were kept for analysis.

Year 3: As in the second year field experiments and greenhouse experiments were conducted with new, G1 and G2 seeds. The same measurements were done and seed samples were kept.

After the field and greenhouse experiments, 72 samples were analyzed by gas chromotography with FID dedector and $60 \mathrm{~m} \times 0.25 \mathrm{~mm}$ ID column for erucic acid content. Statistical Analysis was done by statistical software called MSTAT-C.

\section{RESULTS AND DISCUSSION}

Erucic acid content was ranged between 0.279 and 0.285 for all material. The lowest erucic acid was found in the first genaration. It was increased in the G2 but showed a decrease trend in the G3 generation. However, erucic acid content was not significant from generation to generation (Table 1). When the locations were analyzed, the lowest and highest erucic acid content was in the greenhouse and Bafra $(0.271$ and $0.292 \%$, respectively), but the diffference among locations and greenhouse was not significant. Variety Licrown had lower erucic acid $(0.253 \%)$ than Bristol $(0.303 \%)$, and this difference was significant (Table 1). In G1, erucic acid content of these varieties was similar, but after that Erucic acid content of Licrown reduced a little, and that of Bristol showed an increase. Different trends of varieties for erucic acid was the reason for significant generation $\mathrm{x}$ variety interaction (Fig. 1).

Table 1: Changes in erucic acid content of rapeseeds grown in the field and green house in the Central Blacksea Region

\begin{tabular}{|c|c|c|c|c|c|}
\hline \multirow[t]{2}{*}{ Generations } & \multirow[b]{2}{*}{ Varieties } & \multicolumn{4}{|c|}{ Locations } \\
\hline & & Samsun & Bafra & Green House & Mean \\
\hline \multirow{3}{*}{ Generation 1} & Bristol & 0.280 & 0.281 & 0.280 & 0.280 \\
\hline & Licrown & 0.277 & 0.277 & 0.277 & 0.277 \\
\hline & Mean & 0.279 & 0.279 & 0.279 & 0.279 \\
\hline \multirow[t]{3}{*}{ Generation 2} & Bristol & 0.323 & 0.372 & 0.287 & 0.327 \\
\hline & Licrown & 0.276 & 0.228 & 0.227 & 0.244 \\
\hline & Mean & 0.299 & 0.300 & 0.257 & 0.285 \\
\hline \multirow[t]{3}{*}{ Generation 3.} & Bristol & 0.251 & 0.333 & 0.323 & 0.303 \\
\hline & Licrown & 0.226 & 0.258 & 0.235 & 0.240 \\
\hline & Mean & 0.239 & 0.296 & 0.279 & 0.271 \\
\hline Location mean & & 0.272 & 0.292 & 0.271 & \\
\hline Bristol & & & & & $0.303 \mathrm{a}$ \\
\hline Licrown & & & & & $0.253 b$ \\
\hline
\end{tabular}




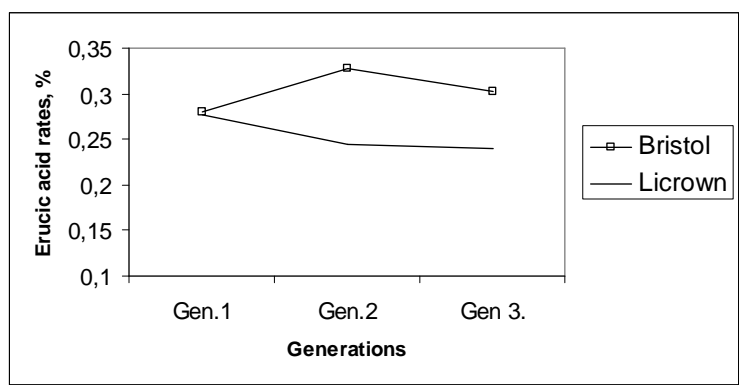

Fig. 1: Effect of generation $\mathrm{x}$ variety interaction on erucic acid content

As a general evaluation, erucic acid contents, which were found in this study for location and generations, are very far away from the limit $(5 \%)$ of human health. However, Khan et al. ${ }^{[8]}$, Bilsbarrow et $a l .{ }^{[9]}$ and Öktem ${ }^{[10]}$ found that when the generation was advanced, erucic acid contenet was increased significantly. Locations, where these studies were conducted, were subject to growing old type rape seeds. However, old type rape seed was not grown Carşamba and Bafra plains. Only sources of cross pollination were cabbages and turnips. Data of this study strongly suggest that cross pollination between rape seed and cabbages and turnip did not occur. These facts were also confirmed by the similarity of results obtained in field experiments and greenhouse experiments.

\section{CONCLUSION}

Farmers anywhere in the world use the same seed for generations or years without renewing particularly those of self pollinated and synthetic varieties. Rape seed have become very famous in Turkish agriculture lately. There are some areas which rape seed has not been produced. Also there is a health concern in public for erucic acid. This study was conducted to answer questions related to cross pollination of rape seed varieties with other Brassica species, and human health concerns.

This study showed that even if farmers did not renew their seeds each year, there would no be any risk for human health related to erucic acid content, and cross pollination between rape seed and other Brassica species could be negligible for erucic acid content.
However, we, agromists, strongly advise farmers to buy new seeds each year for different reasons such as yield and quality advantages and plant breeders rights.

\section{REFERENCES}

1. Röbbelen, G., 1976. Breeding and production of quality rapeseed in Europe. Fette, Seifen, Anstrichmittel, 78: 10-17.

2. Downey, RK, B.M. Craig and C.G. Youngs, 1969. Breeding rapeseed for oil and meal quality. J. Am. Oil. Chem. Soc., 46: 121-123.

3. Zhou, Y.M. and H.L. Liu, 1987. Studies on the inheritance of major fatty acid composition in the oil of rapeseed (Brassica napus L.). Acta Agron. Sinica, 13: 1-10.

4. Fernandez-Escobar, J., J. Dominguez, A. Martin and J.M. Fernandez-Martinez, 1988. Genetics of the erucic acid content in interspecific hybrids of Ethiopian mustard (Brassica carinata Braun) and rapeseed (B. napus L.). Plant Breeding, 100: 310-315.

5. Auld, D.L, K.A. Mahler and D.J. LeTourneau, 1989. Evaluation of four Brassica germplasm collections for fatty acid composition. J. Am. Chem. Soc., 66: 1475-1479.

6. Williams, I.H., A.P. Martin and R.P. White, 1986. The polination requrements of oil-seed rape (Brassica napus). J. Agr. Sci., 106: 27-30.

7. Becker, H.C., R. Karle and S.S. Han, 1992. Environmental variation for outcrossing rates in rapeseed (Brassica napus) Theor. Appl. Genet. 84: 303-306.

8. Khan, S.A., S. Akhtar, I. Waheed and A.H. Khan, 1985. Development of erucic acid and glucosinolate-free rapeseed (crucifers) in Pakistan. 6. Fatty acid composition of the introduced Candle cultivar. Pak. J. Sci. Ind. R., 28: 279-280.

9. Billsbarrow, P.E., E.J. Evans, J. Bowman and B.F. Bland, 1998. Contamination of ediple douple-low oilseed rape crops via pollen transfer from high erucic cultivars. J. Sci. Food Agric., 76: 17-22.

10. Öktem, M., 1988. Tarsus yöresinde yetiştirilen kışlık kolza çeşitleri ve erüsik asit miktarları. Köy Hiz. Gen. Müd. Tarsus Araş. Enst. Yay. 149: 88 . 